\title{
Homeless population: characterization and contextualization by census research
}

\author{
Pessoas em situação de rua: caracterização e contextualização por pesquisa censitária \\ Población en situación de calle: caracterización y contextualización por investigación censal
}

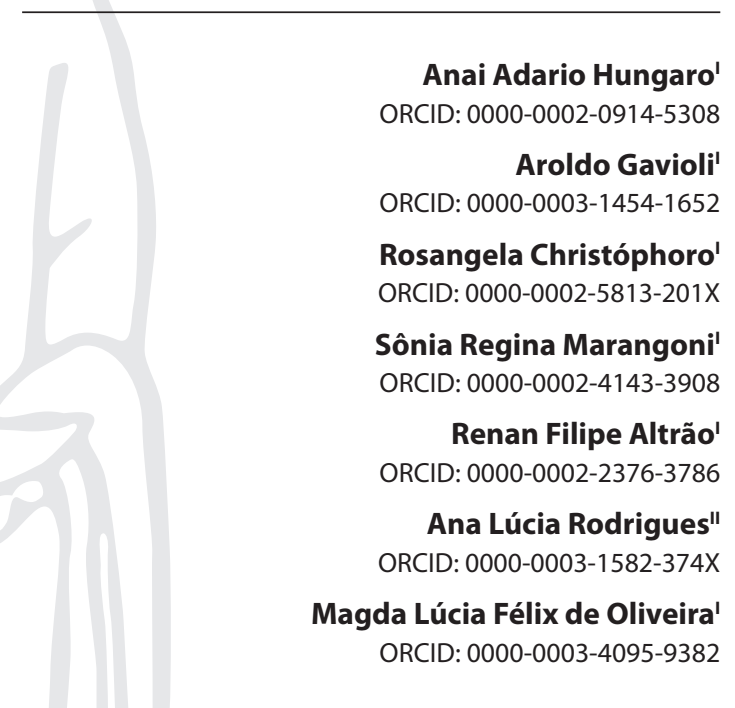

'Universidade Estadual de Maringá. Maringá, Paraná, Brazil. "Universidade Estadual de Maringá, Observatório das Metrópoles. Maringá, Paraná, Brazil.

How to cite this article: Hungaro AA, Gavioli A, Christóphoro R, Marangoni SR, Altrão RF, Rodrigues $\mathrm{AL}$, et al. Homeless population: characterization and contextualization by census research. Rev Bras Enferm. 2020;73(5):e20190236. doi: http://dx.doi.org/10.1590/0034-7167-2019-0236

\section{Corresponding author: \\ Anai Adario Hungaro \\ E-mail: hungaroanai@hotmail.com}

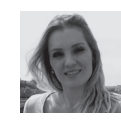

EDITOR IN CHIEF: Antonio José de Almeida Filho ASSOCIATE EDITOR: Alexandre Balsanelli

Submission: 03-31-2019

Approval: 11-06-2019

\section{ABSTRACT}

Objectives: to analyze characteristics of homeless people and factors associated with living on the streets. Methods: a census-type sectional survey carried out between 2015 and 2018, in the municipality of Maringá-Paraná. A total of 701 homeless answered a structured questionnaire with sociodemographic data, living conditions, and drug use. We used Pearson's correlation test for the association analysis of the variables at a $95 \%$ confidence level. Results: men (90.7\%) the average age of 37.7 years had been homeless for an average of 5.39 years. Most had little education (54.2\%), and homelessness was due to drug use (47.2\%) and family disagreements (38.9\%). Conclusions: drug use and family disagreements were the main reasons for homelessness. Time on the street, gender, and drugs were associated with a negative correlation to be homeless; and age, mean daily income, the number of daily meals, having been in prison, and having an income source were associated with positive correlation. Descriptors: Homeless Persons; Censuses; Vulnerable Populations; Street Drugs; Public Health Nursing.

\section{RESUMO}

Objetivos: analisar características das pessoas em situação de rua e fatores associados à vida nas ruas. Métodos: pesquisa seccional do tipo censitário, realizada entre 2015 e 2018, no município de Maringá-Paraná. Um total de 701 pessoas em situação de rua respondeu a um questionário estruturado com dados sociodemográficos e condições de vida e uso de drogas. O teste de correlação de Pearson foi utilizado para a análise de associação das variáveis com nível de confiança de $95 \%$. Resultados: homens $(90,7 \%)$, com idade média de 37,7 anos, estavam em situação de rua há 5,39 anos. A maioria possuía pouca escolaridade (54,2\%), e a situação de rua se devia ao uso de drogas $(47,2 \%)$ e a desentendimentos familiares $(38,9 \%)$ Conclusões: o uso de drogas e os desentendimentos familiares foram os principais motivos para a situação de rua. O tempo na rua, sexo e drogas foram associados a uma correlação negativa para a situação de rua; e idade, renda média diária, número de refeições diárias, ter sido preso e ter uma fonte de renda foram associados a correlação positiva.

Descritores: Pessoas em Situação de Rua; Censos; Populações Vulneráveis; Drogas Ilícitas; Enfermagem em Saúde Pública.

\section{RESUMEN}

Objetivos: analizar las características de las personas en situación de calle y factores asociados a la vida en las calles. Métodos: investigación seccional del tipo censal, realizada entre 2015 y 2018, en el municipio de Maringá-Paraná. Un total de 701 personas en situación de calle ha respondido a un cuestionario estructurado con datos sociodemográficos y condiciones de vida y uso de drogas. El test de correlación de Pearson ha sido utilizado para el análisis de asociación de las variables con nivel de confianza de $95 \%$. Resultados: hombres $(90,7 \%)$, con edad media de 37,7 años, estaban en situación de calle hace 5,39 años. La mayoría tenía escasa escolaridad (54,2\%), y la situación de calle se debía al uso de drogas $(47,2 \%)$ y a los desentendimientos familiares (38,9\%). Conclusiones: el uso de drogas y los desentendimientos familiares han sido los principales motivos para la situación de calle. El tiempo en la calle, sexo y drogas han sido asociados a una correlación negativa para la situación de calle; y edad, renta media diaria, número de comidas diarias, tener sido preso y tener una fuente de renta han sido asociados a la correlación positiva.

Descriptores: Personas en Situación de Calle; Censos; Poblaciones Vulnerables; Drogas Ilícitas; Enfermería en Salud Pública. 


\section{INTRODUCTION}

In the context of social phenomena, being homeless is among those that expose a person to social exclusion ${ }^{(1-2)}$. Homeless, commonly called beggars, wanderers, bummers, and junkies, compose a group characterized by social invisibility, referring to marginality, crime, and drug use $\mathrm{e}^{(3-5)}$.

Brazil does not have official data on the amount of the homeless population. The decennial demographic census and the periodic population counts do not include the investigation of the homeless populations since the census data are collected from the home base. Without housing and a conventional family arrangement, the group remains invisible to the State $\mathrm{e}^{(6-7)}$.

A survey published based on data collected in 2015, estimated that Brazil had over 100,000 homeless people - on sidewalks, squares, highways, parks, under bridges, gas stations, beaches, boats, tunnels, warehouses and abandoned buildings, alleyways, garbage dumps, junkyards or staying over in shelters ${ }^{(7-8)}$.

The homeless population constitute a heterogeneous group, characterized by extreme poverty, interrupted or fragile family bonds and without regular conventional housing, using public places and ruined areas as a living space and to make living, temporarily or permanently, as well as shelter for a temporary living ${ }^{(9-10)}$. The absence of official data on homeless justifies conducting municipal censuses, to implement public policies aimed at reducing their social invisibility.

\section{OBJECTIVES}

To analyze characteristics of homeless people in a medium-sized municipality in the Northern region of Paraná from 2015 - 2018 and factors associated with living on the streets.

\section{METHODS}

\section{Ethical aspects}

We submitted the research project to the Human Research Ethics Committee from the Universidade Estadual de Maringá (State University of Maringá), CAAE (Certificate of Presentation for Ethical Consideration) 02126916800000104. Participants signed the Informed Consent Form - ICF, and the ones unable to sign it, either because of being illiterate or due to physical impairments to sign, using a fingerprint.

\section{Study design}

Census-type sectional research, using intensive diary ${ }^{(11)}$, repeated in the years 2015 to 2018, performed in a single night of fieldwork in the streets of Maringá - PR with notes on data collection, and in different environments with homeless - social entities, health care units, therapeutic communities, non-governmental organizations and police stations during seven days ${ }^{(11)}$.

The Census is an example of descriptive nature research, through the direct observation of a certain planned number of individuals in a single opportunity, applied to society to obtain information about the demographic characteristics of this population ${ }^{(12)}$.

\section{Study period and site}

We conducted the study in the city of Maringá-PR, from 2015 to 2018 , in the urban scenario of the homeless population. The city had an estimated population of 417,010 in 2018, a total territorial area of $487.052 \mathrm{~km}^{2}$, and the Municipal Human Development Index of $0.808^{(13)}$.

The routes and places to access homeless people were established according to the movement of these people and indicated by the Centro de Referência Especializado em Atendimento à População de Rua - Centro Pop (Reference Center Specialized in Attendance to Population Street), which resulted in 12 routes to the investigated population and ten host institutions and shelters.

\section{Population under study}

The study participants were homeless people in Maringá-PR, in the period of the annual censuses, who lived on the streets or were housed in shelters or host institutions, with over 18 years. We excluded the indigenous people, who were on the streets during the daytime and at nighttime were housed in shelters or host institutions, and also people who used the street for an overnight stay.

\section{Study Protocol}

Once we defined the population at a given moment and along the lines of census research, we collected relevant information on characteristics of the homeless people and factors associated with their living in a medium-sized municipality in the Northern region of Paraná in the years 2015 - 2018.

A structured questionnaire was used, with questions related to sociodemographic profile and means for survival on the streets, and questions about living conditions, health and drug use - type, the average age of experimentation and current use.

For a non-domiciled population, we established some procedures distinct from traditional surveys. The interviews were done mostly in the nighttime, previously organized, prioritizing the times with the highest contact with them, when the population was settled to stay overnight in the 12 established routes, to guarantee the approach and interviews without duplicity. The shelters or host institutions were visited along one week, with the permission of the management, at times with the highest stay of users.

A total of fifty researchers - nursing and social sciences professionals, undergraduate and graduate students in psychology, nursing, and social sciences - have been divided annually between the different sites of the city and institutions.

\section{Analysis of results and statistics}

We compiled the data from the Database of the Research Project "Homeless People of Maringá: Deconstructing Invisibility", developed by the Observatório das Metrópoles - Nucleus of the State University of Maringá, using the IBM SPPS ${ }^{\circledR}$ Software. We performed descriptive statistics, using relative and absolute frequencies, as well as measures of dispersion and central tendency and used Pearson's correlation test for the association analysis of the variables, at a confidence level of $95 \%$. 


\section{RESULTS}

A total of 701 street people was interviewed - $160(22.8 \%)$ in 2015, 117 $(16.7 \%)$ in 2016,177 (25.2\%) in 2017 and $247(35.2 \%)$ in the year 2018. A total of $59.6 \%$ ( $\mathrm{n}: 418)$ were homeless, $25.4 \%$ (n:178) were housed in shelters and host institutions, and 15\% (n:105) reported family household, but opted for living on the streets (Table 1).

Regarding the time living on the streets, the time mean was 5.39 years (SD \pm 7.48 ), the median of 2 years and mode of one year, with a minimum time of less than one year and a maximum time of 49 years. The time living on the streets was arranged in 5-year groups, observing that $72.2 \%$ $(n: 506)$ lived in the street from zero to 5 years; $14.8 \%$ ( $n: 104)$ lived on the streets from 6 to 10 years in the research years (Table 1 ).

The average age of the homeless was 37.7 years $(S D \pm 11.43)$, with a median of 36 , mode of 28 years, and minimum and maximum ages were 18 and 77 , respectively. The distribution in age groups showed that $59,6 \%$ (n:418) were in the age group of 25 to 44 years, and 6 participants $(0,9 \%)$ were elderly (Table 1 ).

Regarding the gender of the homeless, $90.7 \%$ (635) were male. The race/color self-reported by most respondents was brown (52.2\%$366)$, and 95 black (13.6\%). A little over half (54.2\%) reported no education or early grades/elementary school, but $24.4 \%$ reported high school education and 3.4\% higher education (Table 1).

Table 2 shows the data on the living conditions and vulnerabilities of homeless. They reported sleeping mainly on sidewalks - 36.4\% (n:255), under awnings - 22.4\% (n:157), and in abandoned houses - $19.1 \%$ ( $\mathrm{n}: 133)$.

The reasons that led these people to live on the streets were drug use, $47.2 \%$ (n:331), family disagreements, 38.9\% (n:273), and unemployment for $25.5 \%$ (n:179). The main reasons for coming to the city of Maringá were job search (29.7\%), family disagreement in the city of origin (16.3\%), or the easiness of living in the city (9.0\%) (Table 2 ).

Concerning the family life of homeless people, $58.5 \%$ ( $\mathrm{n}: 410)$ were single, but $17.4 \%$ ( $\mathrm{n}: 122)$ answered to be married or widowed; $58.8 \%$ had children ( $\mathrm{n}: 412$ ), but only $5.1 \%$ ( $\mathrm{n}: 36$ ) had custody of their children. Family contact occurred in $68.9 \%$ (n:483) of the cases, at least once a week - $63.6 \%$ (n:446).

The sources of income were: begging $-28.7 \%$ (n: 201), watching cars in public spaces $-24.4 \%$ (n:171), collecting recyclables $-15.3 \%$ (n:107), working in construction $14.4 \%$ (n:101) and being a sex worker was pointed out by $10.3 \%$ (n:72), and the daily income was from one to 10 Reais - $6.6 \%$ (n: 46 ) up to 50 Reais $30.4 \%$ (n: 213 ). As for food and daily meals, $28 \%$ ( $n: 196)$ reported four meals a day, but $13.6 \%$ (n: 95 ) had less than one meal a day.
Table 2 - Distribution of the frequencies of living conditions and vulnerabilities of homeless people, Maringá, Paraná, Brazil, 2015 to 2018

\begin{tabular}{|c|c|c|}
\hline & $\mathbf{n}$ & $\%$ \\
\hline \multicolumn{3}{|l|}{ Places homeless sleep* } \\
\hline Sidewalk & 255 & 36.4 \\
\hline Awning & 157 & 22.4 \\
\hline Abandoned house & 133 & 19.1 \\
\hline Square & 124 & 17.7 \\
\hline Host institution & 116 & 16.5 \\
\hline Motel/hostel & 39 & 5.6 \\
\hline Viaduct/small bridge & 34 & 4.9 \\
\hline \multicolumn{3}{|l|}{ Reasons to live on the street* } \\
\hline Drug use & 331 & 47.2 \\
\hline Family disagreement & 273 & 38.9 \\
\hline Unemployment & 179 & 25.5 \\
\hline Freedom/own choice & 137 & 19.5 \\
\hline Divorce & 90 & 12.8 \\
\hline \multicolumn{3}{|l|}{ Reasons to come to Maringá* } \\
\hline Job search & 208 & 29.7 \\
\hline Family disagreement & 114 & 16.3 \\
\hline Easiness of living in this city & 68 & 9.7 \\
\hline Health treatments & 68 & 9.7 \\
\hline To know the city & 55 & 7.8 \\
\hline \multicolumn{3}{|l|}{ Children } \\
\hline Yes & 412 & 58.8 \\
\hline No & 289 & 41.2 \\
\hline \multicolumn{3}{|l|}{ Custody of their children } \\
\hline Mother/Father & 420 & 60.0 \\
\hline Another Family member & 143 & 20.4 \\
\hline Grandmother/Grandfather & 95 & 13.6 \\
\hline Homeless person & 36 & 5.1 \\
\hline Institutionalized/orphanage & 6 & 0.9 \\
\hline
\end{tabular}

Source: Census of Homeless Population 2015-2018, Observatório das Metrópoles, State University of Maringá, 2019.

Note: *More than one answer is possible. 
Table 3 - Distribution of frequencies of drug use in life and age mean of experimentation, Maringá, Paraná, Brazil, 2015 to 2018

\begin{tabular}{lcccccc}
\hline \multicolumn{7}{c}{ Use in life } \\
Drug type & $\mathbf{2 0 1 5}$ & $\mathbf{2 0 1 6}$ & $\mathbf{2 0 1 7}$ & $\mathbf{2 0 1 8}$ & Total & $\begin{array}{c}\text { Average age of } \\
\text { experimentation } \\
\end{array}$ \\
& $\mathbf{n}(\%)$ & $\mathbf{n}(\%)$ & $\mathbf{n}(\%)$ & $\mathbf{n}(\%)$ & & (SD) \\
\hline Tobacco & $138(86.2)$ & $93(79.6)$ & $151(85.3)$ & $211(85.4)$ & $593(84.6)$ & $13.8( \pm 6.5)$ \\
Alcohol & $135(84.4)$ & $99(84.6)$ & $144(81.4)$ & $216(87.5)$ & $594(84.7)$ & $13.8( \pm 6.9)$ \\
Marijuana & $107(66.9)$ & $79(67.5)$ & $117(66.1)$ & $173(70.0)$ & $476(67.9)$ & $14.2( \pm 8.5)$ \\
Inhaled cocaine & $70(43.8)$ & $54(46.2)$ & $75(46.9)$ & $110(44.5)$ & $309(44.1)$ & $15.7( \pm 11.1)$ \\
Crack & $103(64.4)$ & $77(65.8)$ & $104(65.0)$ & $164(66.4)$ & $448(63.9)$ & $14.5( \pm 12.5)$ \\
Amphetamines & $44(27.5)$ & $31(26.5)$ & $40(25.0)$ & $63(25.5)$ & $178(25.4)$ & $15.6( \pm 9.3)$ \\
Inhalants & $68(42.5)$ & $47(40.1)$ & $65(40.6)$ & $101(40.9)$ & $281(40.1)$ & $15.2( \pm 3.4)$ \\
Sedative drugs & $24(15.0)$ & $16(13.7)$ & $23(14.4)$ & $32(13.0)$ & $95(13.5)$ & $17.7( \pm 3.3)$ \\
Hallucionogenic & $23(14.4)$ & $15(12.8)$ & $24(15.0)$ & $33(13.6)$ & $95(13.5)$ & $18.7( \pm 3.0)$ \\
Opioids/opiates & $4(2.5)$ & $4(3.4)$ & $6(3.8)$ & $8(3.2)$ & $22(3.2)$ & $19.4( \pm 3.3)$ \\
Injectable use & $13(8.1)$ & $9(7.7)$ & $15(9.4)$ & $22(8.9)$ & $59(8.4)$ & - \\
\hline Source: Census of Homeless Population 2015-2018, Observatorio das Metrópoles, State University of Maringá, 2019.
\end{tabular}

Table 4 - Distribution of frequencies of drugs current use in the homeless, Maringá, Paraná, Brazil, 2015 to 2018

\begin{tabular}{lccccc}
\hline \multicolumn{5}{c}{ Current use - Years } \\
Drug type & $\mathbf{2 0 1 5}$ & $\mathbf{2 0 1 6}$ & $\mathbf{2 0 1 7}$ & $\mathbf{2 0 1 8}$ & Total \\
& $\mathbf{n}(\%)$ & $\mathbf{n}(\%)$ & $\mathbf{n}(\%)$ & $\mathbf{n}(\%)$ & \\
\hline Tobacco & $106(66.3)$ & $79(67.5)$ & $123(69.5)$ & $171(69.2)$ & $479(68.4)$ \\
Alcohol & $97(60.6)$ & $73(62.4)$ & $110(62.1)$ & $152(61.6)$ & $432(61.6)$ \\
Marijuana & $90(56.3)$ & $63(53.8)$ & $101(57.1)$ & $138(55.9)$ & $392(55.9)$ \\
Inhaled cocaine & $18(11.3)$ & $16(13.7)$ & $21(11.8)$ & $28(11.3)$ & $83(11.9)$ \\
Crack & $92(57.5)$ & $69(59.0)$ & $108(61.0)$ & $148(59.9)$ & $417(59.5)$ \\
Amphetamines & $8(5.0)$ & $5(4.3)$ & $9(5.1)$ & $11(4.5)$ & $33(4.7)$ \\
Inhalants & $16(10.0)$ & $13(11.1)$ & $21(11.9)$ & $31(12.6)$ & $81(11.5)$ \\
Sedative drugs & $5(3.3)$ & $3(2.6)$ & $5(2.8)$ & $10(4.0)$ & $23(3.2)$ \\
Hallucionogenic & $2(1.3)$ & $2(1.7)$ & $3(1.7)$ & $5(2.0)$ & $12(1.7)$ \\
Opioids/opiates & $1(0.6)$ & $1(0.9)$ & $2(1.1)$ & $2(0.9)$ & $6(0.8)$ \\
Injectable use & - & - & - & - & - \\
\hline Source: Census of Homeless Population 2015-2018, Observatorio das Metrópoles, State University of Maringá, 2019.
\end{tabular}

Table 5 - Statistical summary of Pearson's correlation test between outcome variable and sociodemographic variables of 701 homeless people, Maringá, Paraná, Brazil, 2015 to 2018

\begin{tabular}{llcc}
\hline Outcome & Variables & Pearson's R & p value \\
\hline Being & Time living on the streets & -0.139 & $<0.001^{* *}$ \\
homeless & Age & 0.128 & $0.001^{* *}$ \\
& Gender & -0.101 & $0.007^{* *}$ \\
& Drug use & -0.081 & $0.033^{*}$ \\
& To have a job & 0.094 & $0.013^{*}$ \\
& Daily income & 0.135 & $<0.001^{* *}$ \\
& Number of daily meals & 0.180 & $<0.001^{* *}$ \\
& Being in prison & 0.126 & $0.001^{* *}$
\end{tabular}

Source: Census of Homeless Population 2015-2018, Observatory of Metropolis, State University of Maringá, 2019.

Note: ** Correlation is significant at the 0.01 level (2-tailed); ${ }^{*}$ Correlation is significant at the 0.05 level (2-tailed).

Regarding medical conditions, $43.9 \%$ of the homeless reported chronic illnesses, however, $33.4 \%$ (n:234) of them undergo some treatment/follow-up, in which $65.3 \%$ went to basic health units, and $3.3 \%$ received care in the Consultório na Rua (Clinic on the Street). Regarding drug use, $36.7 \%$ ( $\mathrm{n}: 257)$ had been admitted in Therapeutic Communities, and 34.1\% (n:239) were hospitalized in Psychiatric Hospital. Three hundred and twenty-three (46.1\%) had been in Prison, and 7.6\% (n:53) had been hospitalized in Socio-educational Units for under-age offender children.

Use of tobacco and alcohol was more prevalent in life, representing $84.6 \%$ and $84.7 \%$, respectively, and a higher prevalence of current use, with $68.4 \%$ and $61.6 \%$. The age mean of experimentation of the two drugs was on average, below 14 years.

The most prevalent illicit drug use in life was marijuana, with $67.9 \%$, crack, $63.9 \%$, cocaine powder, with $44.1 \%$ and inhalants, $40.1 \%$. These four drugs had average experimentation ages of 14 to 15 years, and prevalence of current use was, respectively, in descending order: crack, marijuana, inhaled cocaine, and inhalants (Table 3).

Club or recreational drugs had the following prevalence of use in life: amphetamine $25.4 \%$, sedative drugs $13.5 \%$, hallucinogenic drugs $13.5 \%$, opioids/opiates $3.2 \%$. The prevalence of current consumption was 4.7\% for amphetamines, 3.2\% for sedative drugs, $1.7 \%$ for hallucinogens, and 0.8 for opioids/opiates. These drugs had averages ages of experimentation between 15 and 19 years (Table 3 ).

Table 4 presents the frequencies of the type of drug used in the studied years. Tobacco and alcohol were the most commonly used licit drugs, and among the illicit drugs were marijuana and crack, respectively (Table 4).

The Pearson's Correlation Test (Pearson's R) aiming to evaluate the statistically significant association, at the $95 \%$ confidence level, between being homeless and socioeconomic variables of the 701 homeless outcomes, pointed out that the variables time living on the streets and gender were statistically associated with the outcome variable in negative correlation; and the variables age, average daily income, number of daily meals and being in prison were significantly associated, at the $99 \%$ confidence level to the outcome variable, being homeless, with positive correlation. The variable drug use was statistically associated, at the 95\% confidence level, with the outcome variable, in negative correlation and, to have a profession, in the sense of positive correlation (Table 5).

\section{DISCUSSION}

The experience of annual censuses presents the characteristics of the urbanization and the socioeconomic development of a municipality of 400,000 inhabitants of the North of Paraná, and we can consider for the findings the improvement in the data collection and a more effective recognition of the places and routes.

The gradual increase in the number of people approached and interviewed in the studied years might indicate the effective increase of homeless people living in the municipality, since 
intermunicipal mobility was mainly for job search and for the easiness of living in the city in this decade of crisis and social inequalities $^{(2,14-15)}$. Another aspect to be considered regards the time they live on the streets, which was significantly higher between 0 to 5 years, and the average of 5.39 years, might indicate the growth of the homeless population in the municipality.

A survey carried out by the Ministério do Desenvolvimento Social (Brazil's Social Development Department) at the end of the 2010s, which considered only Brazilian cities with more than 300,000 inhabitants - 71 municipalities except for the cities of São Paulo, Belo Horizonte, Porto Alegre, and Recife - found 31,722 homeless in these cities $^{(9)}$. We presume that the total homeless living in Brazil was higher in that year since they did not count the homeless in cities with a population of less than 300,000 .

Among countries conducting periodic national census research, in the year 2012, there were over 600,000 homeless people in the United States and the European Union over 400,000, with an increase in each census, and only Finland and the Netherlands reported reductions ${ }^{(16)}$. In 2018 there were 2,181 homeless people in Vancouver, Canada, with a $2 \%$ increase over the previous census, however, this is the highest number since the first regional homeless count in $2005^{(17)}$.

In Brazil, it is estimated 100,000 homeless, being over $75 \%$ in cities with more than 100,000 inhabitants, a high concentration in larger cities, and regional distribution strongly influenced by big cities, where stands out the Southeast region ${ }^{(6-7)}$. In the central countries, the origin and increase of the phenomenon seem to be associated mainly with migratory processes and with the emergence of wars, and in the Latin American countries with poverty and social inequality ${ }^{(2,14)}$.

Being homeless in Brazil easily changes from temporary to permanent, and $30 \%$ of them live under this condition for more than five years ${ }^{(7)}$. It is as a social situation that presents little in terms of overcoming. The process of becoming homeless comes from multiple conditioning factors, the reason why the intervention with those who have been living on the streets for less time seems to be central to achieve greater effectiveness in terms of public policy ${ }^{(2,10,15)}$.

The profile of homeless living in the streets of Maringá follows the trend of national and international studies ${ }^{(9,15,17-20)}$. Most homeless are men, and in Maringá, it rates above $90 \%$ young people - the predominant age group is 26 to 35 years -, with low schooling, brown and black color/race, and they have some source of income activity.

In the IBGE census - which gathers black and brown color/ race - the Brazilian population accounts for $53 \%$ of blacks and $46 \%$ of whites ${ }^{(9)}$. Considering the homeless population, if we use the same method, the black in our study is $65.8 \%$ - higher than in the Brazilian population.

Contrary to common sense, a large proportion of homeless carry out some source of income activity and claim to have a profession, even though it is part of the so-called informal economy, in which there is no formal job, official hiring and contract. The activities most carried out by them are those of collectors of recyclable materials, car watchers, construction workers. Many of the homeless do not beg to survive, in most cases there is work, but there is no hiring, which contradicts the popular logic that this would be a population that does not work, which justifies studies and interventions on the "work" them with these population ${ }^{(9,21)}$.
Regarding work and special populations, it is noteworthy that not everyone is qualified and capable enough for the formal labor market, in the sense of entering and staying in it, which makes a large contingent of workers vulnerable, including those affected by unemployment and lack of occupation. In this context, without work stability and guaranteed rights, the situation is seen as a dead-end, since it is a permanent threat, being left outlaw activities, side jobs, and small occupations as an alternative for survival(22).

One of the human needs added to income is food. There is no time to eat, but most of them know the points that provide food and the times in which this happens ${ }^{(23)}$, and in Maringá, 25\% of those surveyed reported they ate four meals a day.

The health of homeless people is among the worst of any vulnerable group, and national and international studies address several issues that go through the health of homeless people, especially the difficulties in accessing health services, meanings and health/disease practices, drug use, and psychiatric disorders ${ }^{(24-26)}$.

However, important milestones for the homeless were established in the National Policy for Homeless, to assert the rights of this population, as well as stipulate conditions of equality and equity for the homeless ${ }^{(9)}$. Homeless is entitled to all the services available in the Unified Health System, such as the Basic Health Units, Emergency Care Units, Psychosocial Care Centers, the Mobile Emergency Care, and the health strategy of the Consultório na Rua (Clinic on the Street) ${ }^{(27)}$.

The Consultório na Rua (Clinic on the Street is an action instituted based on the National Primary Care Policy, and its objective is to expand the access of the homeless to health services, in a more accessible way, and it has team composed of several health professionals, such as a medical doctor, nurse, psychologist, and social worker ${ }^{(28)}$.

There are multiple factors for becoming homeless; hardly a single factor will lead to this situation ${ }^{(20)}$. The main reasons why these people started living in the streets refer to problems with drugs; unemployment and family disagreements ${ }^{(9,14)}$. They report family disagreements and drug use as reasons for going to the streets, but we can question whether the permanence in the streets may be related to these findings. Caution is needed when stating that people are homeless because of the drug use, as it is difficult to measure whether drug use is a "cause" for homelessness or "consequence", in which drugs led them to be homeless, or was it the opposite, living on the streets that were central for drug use in their subsistence? ${ }^{(20,29)}$.

They have to deal with unfavorable living conditions on the street such as violence - many of them have already been in prison - lack of basic sanitation and hygiene, lack of food, lack of beds in public shelters and host homes (a problem in most cities), and being constantly away from family. In the study, many reported having children and not living with them, which leads to a highly stressful condition. Homeless can develop psychiatric disorders and drug use in response to difficult living conditions, being threatened by violence, hunger, and lack of shelter and care. The conditions in which they live not only relate to their characteristics but also to their context and other programmatic issues, which influence the vulnerability situation of an individual or social group ${ }^{(30)}$.

Other national and international researches have also studied drug abuse, especially alcohol, in the homeless population, factor 
mentioned repeatedly in the speeches of several interviewees in Maringá ${ }^{(9,17-20)}$. The authors of these studies are emphatic in pointing out the need for integration between social policies to face situations of becoming homeless, stressing the importance of ensuring that this population has access to treatment in mental health in an articulated way to other policies.

Socially excluded populations, such as homeless, prisoners, sex workers, and drug users, have mortality rates about eight times higher for men and 12 times higher for women, associated with moderate or extreme inequalities ${ }^{(31)}$. Globally, between 41 and $84 \%$ of adult homeless use drugs ${ }^{(32)}$; in Brazil, an average of $80 \%$ of the homeless use drugs ${ }^{(18)}$, and this index is approximately $79 \%$ in the city of Maringá - $\mathrm{PR}^{(33)}$. In many cases, drug abuse is concomitant with mental disorders, and risk to violence or victimization $^{(32)}$.

According to research by the Substance Abuse and Mental Health Services Administration ${ }^{(34)}$, drug abuse is more common among homeless people than among the general population. The results of the survey point that drug abuse was $26 \%$ among the homeless, and use is predominant among younger people, and $38 \%$ of this population drinks alcohol, which is predominant among the older population ${ }^{(34-35)}$.

A qualitative study with the purpose of knowing aspects of the living, health, and illness of the homeless population in Maringá - PR, found drugs as part of the lives of six out of eight interviewees, when asked "what is it like to be healthy being a homeless?", they pointed to difficulties in health care, because they did not find health care services for their needs, did not have financial resources or family support, and faced denial of their life condition by other people and by themselves ${ }^{(36)}$.

Although alcohol and tobacco are statistically the most used drugs by this population, crack represents a serious problem due to individual consequences, aggravating the street environment and it is a challenge for public health policies, especially for primary health care policies, because of an observed increase in the prevalence of this use ${ }^{(37)}$.

\section{Study limitations}

The drug use, social vulnerability, and mental health of the study population can influence the information gathered about the homeless. However, the group of researchers has been trained in methodologies to approach vulnerable people and to formulate the questions to reduce this limitation.

The methodology of the census, by immersion in a week may not reach all homeless people, because it is a floating population
- temporarily housed in relatives' homes or institutions, or temporarily displaced to other municipalities. This condition reinforces the need for a follow-up study with this population.

Nevertheless, it is not possible to assert that a longer period for data collection would be better since it would be possible to count them more than once, or the homeless could have left the city since they are floating populations.

\section{Contributions to the Field}

Approaching this population, getting to know their way of living, the drug use and health in their environment would allow identifying peculiar aspects to propose alternatives that can contribute to their visibility and subsidize the creation and implementation of public policies for the impact of a hostile environment such as living on the streets. The study may also contribute to a less stigmatized and prejudiced view of the homeless so that health professionals can work to reduce the suffering of this population.

Nurses, and specifically Public Health nurses, are often the first health care providers to meet people who are homeless and are highly effective in involving this population in various educational and skills activities, to produce positive health outcomes and reduce risk behaviors ${ }^{(2)}$.

\section{CONCLUSIONS}

We consider as the differential of the study population the mental vulnerability, poor use of Consutório na Rua (Clinic on the Street) and frequent mention of social support homes, search for work and income beyond begging, and recognition of heterogeneity. They reported family disagreements and drug use as the main reasons for living on the streets, but we can question whether staying in the streets may be related to these findings.

Time living on the street, gender, and drug use was associated with a negative correlation to be homeless; and age, mean daily income, the number of daily meals, having been in prison, and having work was associated with positive correlation.

We suggest the creation of different strategies that contemplate the particularities of this group to allow the surpassing of the processes of becoming homeless, avoiding massive approaches, and it is emphasized the indispensable participation between state and society for the overcoming of stigmas and prejudices, from social research, inclusion of the theme in teaching, debate, use of the media and social networks, so that these subjects can be visible as subjects with rights.

\section{REFERENCES}

1. Feltran G, Arretche, M. New faces of life on the streets. In: Presentation. São Carlos. SP: EduFSCar, 2016.

2. Weber JJ. A systematic review of nurse-led interventions with populations experiencing homelessness. Pub Health Nurs. 2018;36(1):96-106. doi: $10.1111 /$ phn. 12552

3. Rui T, Martinez M, Feltran G. New faces of life on the streets. In: Preface. São Carlos. SP: EduFSCar; 2016.

4. Santa Maria DM, Narendorf SC, Cross MB. Prevalence and correlates of substance use in homeless youth and young adults. J Addict Nurs. 2018.29(1):23-31. doi: 10.1097/JAN.0000000000000206 
Homeless population: characterization and contextualization by census research

5. Aldridge RW, Story A, Hwang SW, Nordentoft M, Luchenski SA, Hartwell G, et al. Morbidity and mortality in homeless individuals, prisoners, sex workers, and individuals with substance use disorders in high-income countries: a systematic review and meta-analysis. Lancet. 2018;391(10117):241-50. doi: 10.1016/S0140-6736(17)31869-X

6. Figueiredo EHL, Guerra DLR. From the homeless: the criminalization of the invisible. RIPE [Internet]. 2016 [cited 2019 Mar14];50(66):160-76. Available from: http://ojs.ite.edu.br/index.php/ripe/article/view/265/292

7. Natalino MAC. Estimates of the population living on the streets in Brazil. IPEA TD2246 [Internet]. 2016 [cited2019 Mar14]. Available from: http://www.ipea.gov.br/portal/index.php?option=com_content\&id=28819

8. Instituto de Pesquisa Econômica Aplicada. IPEA. Estimates of the homeless population in Brazil [Internet]. 2016. [cited 2018 Apr 18]; Available from: http://www.rcdh.es.gov.br/sites/default/files/2016\%20IPEA\%20Estimativa\%20da\%20populacao\%20de\%20rua\%20no\%20Brasil.pdf

9. Ministério de Desenvolvimento Social (BR). Ministry of Social Development and Fight against Hunger. National survey of the homeless population. Brasília: MDS, 2008.

10. Van Straaten B, Rodenburg G, Van der Laan J, Boersma SN, Wolf J, Van de Mheen D. Changes in social exclusion indicators and psychological distress among homeless people over a 2.5-year period. Soc Indicat Res. 2018;135:291-311. doi:10.1007/s11205-016-1486-z

11. Feltran GS. [Intensive diary: the question of the "adolescent in conflict with the law", in context]. Rev Bras Adolesc Conflitualidade [Internet]. 2011 [cited 2019 Mar 14];1:01-44. Available from: http://revista.pgsskroton.com.br/index.php/adolescencia/article/view/261 Portuguese

12. Godoy MM, Paiva CA. A study of the quality of census information in nominative lists and an approximation of the occupational structure of the province of Minas Gerais. Rev Bras Estud Pop [Internet]. 2010[cited 2019 Mar 11];27(1):161-91. Available from: http://www.scielo.br/pdf/ rbepop/v27n1/10.pdf

13. Instituto Paranaense De Desenvolvimento Econômico E Social-Ipardes. Caderno estatístico do município de Maringá. p. 1-43, maio, 2018.

14. Resende VDM, Ramalho IDS. Media representation of violation of rights and violence against homeless people in Correio Web. Calidoscópio. 2017;15(3). doi: 10.4013/cld.2017.153.11

15. Tweed EJ, Rodgers M, Priyadarshi S, Crighton E. "Taking away the chaos": a health needs assessment for people who inject drugs in public places in Glasgow, Scotland. BMC Public Health [Internet]. 2018 Jul 4;18(1). doi: 10.1186/s12889-018-5718-9

16. Brussels. Commission Staff Working Document. Confronting homelessness in the European Union. European Commission; Brussels, 2013.

17. Vancouver Homeless Count, 2018. Non-Profit Housing Association. https://vancouver.ca/files/cov/vancouver-homeless-count-2018-finalreport.pdf

18. Fundação Instituto de Pesquisas Econômicas. Census survey of homeless population, socioeconomic characterization of the adult homeless population and thematic report to identify the needs of this population in the city of São Paulo [Internet]. 2015[cited 2019 Mar 11]. Available from: https://www.prefeitura.sp.gov.br/cidade/secretarias/upload/00-publicacao_de_editais/0001.pdf

19. Kunz GS, Heckert AL, Carvalho SV. The ways of life of the homeless: inventing tactics in the streets of Vitória/ES. Fractal, Rev Psicol. 2014;26(3):919-42. doi: 10.1590/1984-0292/1192

20. Tiengo VM. The Phenomenon Population in Street Situation as a Fruit of Capitalism. Textos Contextos. 2018;17(1):138-50. doi. $10.15448 / 1677-9509.2018 .1 .29403$

21. Schmitt AA, Schweitzer L. People living on the streets and work: experience report of people on the streets. Estud Contemp Subjet. $2016 ; 7(1)$.

22. Barros VA. Social Exclusion and Integration through Labor. In: Bendassolli PF; Borges-Andrade JE. Dicionário de Psicologia do Trabalho e das Organizações (Orgs). São Paulo: Casa do Psicólogo, 2015.

23. Sotero M. Vulnerability and vulneration: street population, an ethical issue. Rev Bioét [Internet]. 2011[cited 2019-03-11];19(3):799-817. Available from: http://revistabioetica.cfm.org.br/index.php/revista_bioetica/article/view/677/727

24. Barata RB, Carneiro JN, Ribeiro MCSA, Silveira C. Health social inequality of the homeless in the city of São Paulo. Saude Soc. 2015;24(Supl1):219-32. doi: 10.1590/s0104-12902015s01019

25. Bonugli R, Lesser J, Escandon S. The second thing to hell is living under that bridge: narratives of women living with victimization, serious mental illness, and in homelessness. Issues Ment Health Nurse. 2013; 34(11):827-35. doi: 10.3109/01612840.2013.831149

26. Riley ED, Shumway M, Knight KR. Risk factors for stimulant use among homeless and unstably housed adult women. Drug Alcohol Depend. 2015;153:173-9. doi: 10.1016/j.drugalcdep.2015.05.023

27. Olveira SRA, Barzaghi N, Historical reflection on the population in street situation and publics policies. Rev Uningá Review. 2017;29(1):237-45.

28. Paula HC, Daher DV, Koopmans FF, Faria MGA, Brandão PS, Scoralick GBF. Implementation of the Street Outreach Office in the perspective of health care. Rev Bras Enferm. 2018;71(Suppl 6):2843-7. doi: 10.1590/0034-7167-2017-0616

29. Duchesne A, Rothwell DW. What leads to homeless shelter re-entry? An exploration of the psychosocial, health, contextual and demographic factors. Can J Public Health. 2015;107:94-9. doi: 10.17269/cjph.107.5271

30. Neves-Silva P, Martins Gl, Heller L, "We only have access as a favor, don't we?"The perception of homeless population on the human rights to water and sanitation. Cad Saúde Pública. 2018;34(3):e00024017. doi.org/10.1590/0102-311x00024017 
31. Aldridge R, Zenner D, White P, Williamson E, Abubakar I, Hayward A. Pre-entry screening of tuberculosis in migrants to the UK: a populationbased cohort study. Lancet. 2016;387:S11. doi: 10.1016/S0140-6736(16)00398-6

32. Tsai J, Kasprow WJ, Rosenheck RA. Alcohol and drug use disorders among homeless veterans: prevalence and association with supported housing outcomes. Addict Behav. 2014;39(2):455-60. doi: 10.1016/j.addbeh.2013.02.002

33. Observatório Das Metrópoles. Research in homeless Population 2016. Coordenação Geral: Ana Lúcia Rodrigues, Coordenação Técnica: Wesley O. Furriel, 2016.

34. Department of Health and Human Services (US). Substance Abuse and Mental Health Services Administration Samhsa. Reports and Detailed Tables From the 2016 National Survey on Reports and Detailed Tables From the 2016 National Survey on Drug Use and Health (NSDUH). Rockville, Maryland, 2016.

35. Mc Cormack RP, Hoffman LF, Norman M, Goldfrank LR, Norman EM. Voices of homeless alcoholics who frequent Bellevue Hospital: a qualitative study. Ann Emergency Med. 2015;65(2):178-86. doi: 10.1016/j.annemergmed.2014.05.025

36. Procidonio GS. Homeless of Maringá - Paraná: aspects of living, health and disease. Completion work - TCC (Undergraduate Nursing) -State University of Maringá. Advisor: Magda Lúcia Félix de Oliveira. Maringá, 2015.

37. Prates JC, Prates FC, Machado S. Homeless population: the precarious exclusion and inclusion processes experienced by this segment. Temporalis, Brasilia (DF), 2011;22:191-215. 